
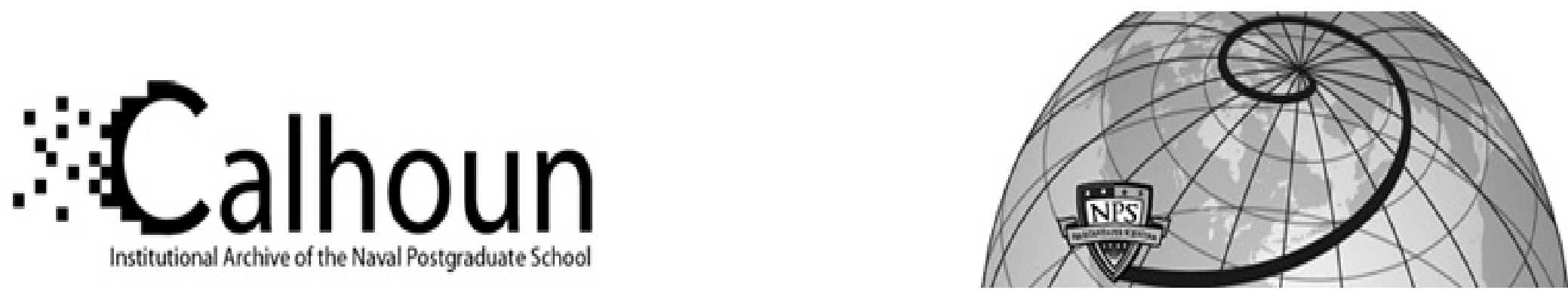

Calhoun: The NPS Institutional Archive DSpace Repository

Leveraging strategic sourcing and knowledge management to improve the acquisition of knowledge-based services

Hawkins, Timothy G.; Nissen, Mark E.; Rendon, Rene G.

Journal of Public Procurement, Volume 14, Issue 21, pp. 215-251, Summer 2014 https://hdl.handle.net/10945/45134

This publication is a work of the U.S. Government as defined in Title 17, United States Code, Section 101. Copyright protection is not available for this work in the United States.

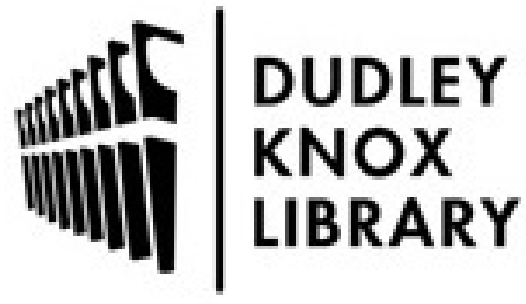

http://www.nps.edu/library
Calhoun is the Naval Postgraduate School's public access digital repository for research materials and institutional publications created by the NPS community. Calhoun is named for Professor of Mathematics Guy K. Calhoun, NPS's first appointed -- and published -- scholarly author.

Dudley Knox Library / Naval Postgraduate School 411 Dyer Road / 1 University Circle Monterey, California USA 93943 


\title{
LEVERAGING STRATEGIC SOURCING AND KNOWLEDGE MANAGEMENT TO IMPROVE THE ACQUISITION OF KNOWLEDGE- BASED SERVICES
}

\author{
Timothy G. Hawkins, Mark E. Nissen and Rene G. Rendon *
}

\begin{abstract}
Knowledge-based services (KBS) comprise a major portion of services acquired by public organizations. However, their procurement is not well managed; consequently, inefficiencies abound. Therefore, this study explores whether and how KBS can be sourced more efficiently by examining best practices and precepts from knowledge management theory. A spend analysis of one agency's spend is used to identify the types of KBS procured. Interviews from 12 cases are then used to identify best practices and cost drivers in sourcing KBS. Twenty one recommendations for improving efficiency in sourcing KBS are offered. The findings suggest that potential is available from demand reduction strategies, and that public policy governing the procurement of knowledge is needed. The research concludes with theoretical implications and suggestions for future research.
\end{abstract}

\section{INTRODUCTION}

Federal, state, and local governments face pressure for cost savings (McCue \& Johnson, 2010; Waterman \& McCue, 2012) due to decreased revenues resulting from the recent economic crisis, and

* Timothy G. Hawkins, Ph.D., CPCM, C.P.M., is an Assistant Professor, Department of Marketing, Western Kentucky University. His current research interests include electronic reverse auctions, procurement ethics, buyer-supplier relationships, strategic sourcing, services procurement, and supplier performance management. Mark E. Nissen, Ph.D., is Professor of Information Science and Management, and Director of the Edge Center, Naval Postgraduate School. His research focuses on dynamic knowing and organizing. Rene G. Rendon, D.B.A., CPCM, CPSM, C.P.M., PMP, is an Associate Professor, Graduate School of Business and Public Policy, Naval Postgraduate School. His research focuses on contract management process maturity, services contract management, and public procurement policy.

Copyright @ 2014 by PrAcademics Press 
face rising operating costs. Procurement is a significant area of cost that is garnering greater attention from managers and scholars (Husted \& Reinecke, 2009). It is estimated that procured products and services comprise one third of total public expenditures (Husted \& Reinecke, 2009). Services represent a growing proportion of procurement spending. Governments commonly outsource a plethora of services such as public transportation, food service, vehicle fleet management, security, grounds maintenance, information technology, engineering, professional services, and management consultants, just to name a few.

Service purchasing is on the rise (Dewhurst, Ellsworth, \& Hancock, 2013; Husted \& Reinecke, 2009). The United States Department of Defense (DoD) obligations for service contracts doubled between fiscal years 2001 and 2008, from \$92 billion to $\$ 200$ billion (GAO, 2009). This increase in services purchasing coincided with a reduction in the DoD acquisition workforce. The DoD acquisition workforce fell from approximately 500,000 personnel in 1990 , to approximately 200,000 personnel in 2006-a decrease of 65 percent (Rendon, Apte, \& Apte, 2012). Since the requisite infrastructure in terms of processes and human resources involved in service purchasing is not commensurate with its growth, there is ample opportunity for organizations to improve their purchasing of services (Ellram, Tate, \& Billington, 2007; Apte, Apte, \& Rendon, 2011).

Many factors contribute to the relative neglect of purchasing professionally managed services (Ellram, Tate, \& Billington, 2007). These factors include a lack of resources, inadequate information technology, and a lack of understanding cost structures (Ellram, Tate, \& Billington, 2007). Moreover, due to the peculiar nature of services, it is difficult to develop service specifications (Schiele, 2009), to evaluate services in advance of performance, and to quantify the costs of services (van der Valk \& Rozemeijer, 2009). Problems arising from not understanding cost drivers are particularly acute in the public sector where agencies lack a profit motive and are not held accountable for minimizing costs. Poor services purchasing management and fragmented service spending can have harmful effects on the organization's performance (Ellram, Tate, \& Billington, 2007). 
Among the fastest growing services - and the most problematic to manage - is knowledge-based services. Between FY2005 and FY2011, the DoD increased the use of knowledge-based services from $\$ 28.3$ billion to $\$ 45.2$ billion (DPAP, 2012; GAO, 2007a). Knowledge-based services are defined as those that "support or improve organizational policy development, decision-making, management and administration, program and/or project management and administration, or research and development activities" (DAU, n.d.). The DoD currently spends more on knowledgebased services than on major weapons systems (Sablan, 2011).

Strategic sourcing emerged in the for-profit sector as a powerful means to combat inefficiency and improve an organization's effectiveness and competitive advantage (McCue \& Johnson, 2010). Strategic sourcing was heralded as a key means by which IBM saved $\$ 6.5$ billion and survived its near-death experience in the early 1990s (Nelson, Moody, \& Stegner, 2001). Public agencies have experienced a notable average savings of 28 percent from strategic sourcing initiatives (Husted \& Reinecke, 2009). The state of Georgia saved $\$ 100$ million annually from its implementation of strategic sourcing (Pennington, 2011). Nonetheless, the U.S. federal government hardly broached the tip of the iceberg; only five percent of contracts have been strategically sourced (GAO, 2012).

Efficiently and strategically sourcing knowledge-based services has garnered limited scholarly attention, particularly in the public sector. Outside of a few findings (Levina \& Su, 2008, Hancock \& Ellsworth, 2013), we don't know the extent to which knowledge-based services can be procured more efficiently, nor do we know the specific tactics to do so. Public agencies struggle to measure and mitigate total ownership costs. They also struggle to accurately and consistently measure cost savings (AFAA, 2010). Additionally, rarely are public employees rewarded for cost savings. In fact, there is a negative incentive to save funds since savings that go back to the Treasury cannot be used and due to the common belief that savings will result in a decreased future budget (Husted \& Reinecke, 2009). As such, there is currently no cost-savings framework or set of best practices for efficiently sourcing knowledge-based services to ensure that stakeholders (i.e., taxpayers) receive the best possible results at the least possible total ownership costs. 
The purpose of this research, therefore, is to explore how the public sector can improve efficiency in sourcing knowledge-based services. Specifically, the following research questions will be addressed:

- Which strategic sourcing strategies are relevant to knowledgebased services?

- What are best practices in sourcing knowledge-based services?

- What are the different types of knowledge-based services being procured?

- Of the different knowledge-based services, what are the major cost drivers?

Such research is important because government agencies are increasingly being asked to provide more and improved public services with smaller budgets.

To address these research questions, we first scanned extant literature addressing services, strategic sourcing, and knowledge management. We then interviewed organizational buyers from the for-profit and not-for-profit sectors to unveil best practices for strategically sourcing knowledge-based services. From a sample of spend data from one federal public agency, we conducted a spend analysis of procured knowledge-based services to identify the various types of services. Then, we provided an analysis of the interview and spend data, followed by a discussion, managerial and theoretical implications, and a set of recommendations for practitioners.

\section{LITERATURE REVIEW}

In order to examine the efficiency of purchased knowledge-based services, it is important to review: (1) the characteristics of these services, (2) knowledge management theory, and (3) the relevant tenets of strategic sourcing.

\section{Services}

Services are often difficult to define, but most definitions include the characteristics of intangibility, heterogeneity, perishability of output, and simultaneity of production and consumption (Fitzsimmons \& Fitzsimmons, 2008). More specifically, Lovelock and 
Wirtz (2007) discussed eight characteristic that suppliers of services face:

- Most service products cannot be inventoried.

- Intangible elements usually dominate value creation.

- Services are often difficult to understand and difficult for customers to evaluate.

- Customers may be involved in co-production.

- People may be part of the service experience.

- Operational inputs and outputs tend to vary more widely; thus, quality control standards pose challenges.

- The time factor often assumes great importance.

- Distribution may take place through nonphysical channels.

Unlike commodities, many services cannot be stored unless previously recorded electronically or physically for later use (Lovelock $\&$ Wirtz, 2007). Like unused manufacturing space waiting to produce commodities, services may also have unused capacity (e.g., facilities, equipment, labor) in anticipation for services not rendered (Lovelock \& Wirtz, 2007). Over or underutilization of capacity is very challenging for managers due to customer variations that offer no inventory to absorb these lost opportunities (Fitzsimmons \& Fitzsimmons, 2008). This unused capacity causes losses of time and money. Likewise, overcapacity can forgo profits.

Customers also face the intangibility issue because, in many cases, they cannot see the service that they are purchasing. There are also services that contain both intangible services and commodities such as a mechanic who rebuilds parts for resale.

Another issue with services is that they are not always easy to envision and comprehend. Often, first-time customers lack the knowledge or insight to anticipate the outcome of the service making it difficult to trust the provider (Lovelock \& Wirtz, 2007). The customer must rely on the provider's brand name or on reviews from repeat customers to make an informed decision.

Many customers co-produce the service process every day and do not realize it. Personnel participate in such things as providing food services at a dining facility, meeting with consultants, or applying 
themselves in their education (Fitzsimmons \& Fitzsimmons, 2008). Therefore, service providers must be able to manage their customers and accommodate their needs.

Many of the characteristics of services have implications to the means by which services are procured. Insights should also be available from examining the outputs of knowledge-based services knowledge.

\section{Knowledge Management}

Knowledge management is defined as "performing the activities involved in discovering, capturing, sharing, and applying knowledge so as to enhance, in a cost-effective fashion, the impact of knowledge on the unit's goal achievement" (Becerra-Fernandez \& Leidner, 2008, p. 6). Effective knowledge management within an organization can lead to a competitive advantage. On average, companies that effectively managed their knowledge achieved a 5 percent increase in their return on sales, return on assets, operating income to assets, and operating income to sales (Holsapple \& Wu, 2011). Benefits of effective KM include superior knowledge acquisition, superior storage and retrieval, superior sharing and dissemination, and superior decision making (Holsapple \& Wu, 2011).

The increased turnover in employees causes firms to continuously figure out ways to capture knowledge from their employees, suppliers, and purchasers to obtain a competitive advantage. For employers to capture knowledge from their employees, they must understand the difference between tacit and explicit knowledge. Explicit knowledge is articulated in some sort of trade secret, patent, copyright, process, written instructions, or documents (Nissen, 2006). Tacit knowledge, on the other hand, is knowledge specific to an organization and gained through experience (Nissen, 2006). Tacit knowledge is often more powerful than its explicit counterpart (e.g., reading a book about flying an airplane is not the same as experiencing flying), but it is problematic also: it does not flow freely; it is difficult to transfer; it is not easily understood by others; and it is often taken for granted until it is gone (Nissen, 2006). This is the case in particular when tacit knowledge walks out the door in the minds and experiences of seasoned professionals who retire, quit, transfer or otherwise leave an organization's service. 
Knowledge flow within an organization, whether tacit or explicit, is only as good as the method that employees within a firm use to start and keep it flowing. Tacit knowledge tends to flow within an organization very slowly, whereas explicit knowledge tends to flow very broadly and quickly. Activity is the key to knowledge flow (Nissen, 2006). Similar to Newton's law of motion, knowledge confined within an individual, or even in an IT system, tends to stay at rest unless there is some sort of activity (e.g., training, mentoring, research, trial and error, discussion) to spark the learning process (Nissen, 2006, p. 34). Activity causes continuous learning, whether it is in the business or academic realm. Although some of this knowledge is not equally distributed (especially across novices and experts), the more knowledge a firm applies through action and performance, the more likely the organization will gain a competitive advantage.

Experience accumulation, knowledge articulation, and knowledge codification are the three learning mechanisms in the development of dynamic knowledge flow capabilities within an organization (Winter \& Zollo, 2002). Experience accumulation is experiential learning through trial and error of tacit knowledge and explicit routines. Knowledge articulation refers to implicit knowledge articulation through constructive confrontations of colleagues in order to understand how to execute and perform a task better. Knowledge codification refers to the documented codification of an individual's understanding of performance implications and routines.

Four main obstacles prevent the flow of knowledge within an organization (Nissen, 2006). First, inactive knowledge not flowing within an organization - tacit or explicit - is underutilized. Sometimes employees fear that giving up knowledge, especially when competing against others, will make them less valuable (Hansen \& Nohria, 2004). Additionally, employees may retain knowledge because they do not have time to help others and because they want to retain knowledge to obtain a good evaluation (Hansen \& Nohria, 2004). Sometimes, power and influence can also cause people to manipulate or withhold their knowledge (Hartley, Rashman, \& Withers, 2009).

Next, a person must have the ability to learn so that he or she can create and share reliable knowledge. Sometimes people within a department or group tend to value their own viewpoints and beliefs, 
resulting in the rejection of external knowledge (Hansen \& Nohria, 2004). Additionally, employees may not have the time or resources available to obtain knowledge while on the job or through higher education.

Third, once the person is competent, he or she must be willing to share knowledge and transfer it effectively. Employees who have not learned to work together or who are from different organizations tend to have difficulty in transferring tacit knowledge (Hansen \& Nohria, 2004). Additionally, cultural issues such as beliefs, trust, leadership, relationships, social media, and internal and external networks can impair knowledge transfer (Hartley, Rashman, \& Withers, 2009).

The last obstacle is that a person must have internalized knowledge before he or she can apply or share it. Employees may find it difficult to locate expert personnel or information required to complete a task, resulting in lost knowledge by the employee and less efficient work (Hansen \& Nohria, 2004). Although these obstacles may seem simple, not all people are free and willing to learn, share, or manage knowledge.

Leaders may overcome these obstacles to knowledge flow in five ways (Nissen, 2006). First, managers and leaders must allow and encourage the appropriate knowledge to flow within their organization. Next, managers and leaders need to understand the type of knowledge required (tacit or explicit) and how accessible the knowledge is for a particular task. Another way to overcome knowledge-flow obstacles is for managers to ensure that all the required knowledge flows are complete and that the critical path is identified prior to employees' performing work, thus eliminating wasted time and resources. The fourth way to overcome the obstacles is for managers to consider the premium on workflows versus knowledge flows within the organization. Here, managers must decide whether a task requires learning the task through education or learning by doing the task. Finally, Nissen (2006) recommended that managers need a model to pull together the various factors, considerations, and alternatives associated with workflows and knowledge flows and to help support informed decision making.

Other means to overcome obstacles to knowledge flow have emerged. First, leadership must demonstrate and emphasize the importance of collaboration, articulate teamwork values, and develop 
unified goals in order to motivate employees to seek or share knowledge (Hansen \& Nohria, 2004). Next, employers should use a willingness to seek or provide help as a criterion for hiring and promoting personnel. Finally, employers must develop a means of cross-cultivating relationships within an organization, establish a directory of experts by area, and develop a benchmark system that allows employees to identify best practices. IBM offered five roadblocks that organizations face in knowledge flow (Fontaine \& Lesser, 2002):

- failure to align knowledge management efforts with the organization's strategic objectives;

- creation of repositories without addressing the need to manage content;

- failure to understand and connect knowledge management into individual's daily work activities;

- an overemphasis on formal learning efforts as a mechanism for sharing knowledge; and

- focusing knowledge management efforts only within organizational boundaries. (p. 1)

After examining services and knowledge management, strategic sourcing concepts may be applied to determine a fit between characteristics of knowledge-based services, the outcome of such services, and how they are defined and sourced from suppliers.

\section{Strategic Sourcing}

Strategic sourcing is defined as "a collaborative and structured process of critically analyzing an organization's spending, and using this information to make business decisions about acquiring commodities and services more effectively and efficiently" (OMB, 2005, p. 1). Fourteen underlying tenets (Reese \& Pohlman, 2005) summarize the phenomenon (Table 1). These tenets are not constrained to for-profit-sector firms; public agencies can use strategic sourcing to lower total ownership costs and achieve government objectives (McCue \& Johnson, 2010).

There are generally three means to achieve savings - rate reductions, demand reductions, and process efficiencies (Anderson \& Katz, 1998). Often, savings are available in total costs of ownership 
TABLE 1

Strategic Sourcing Tenets

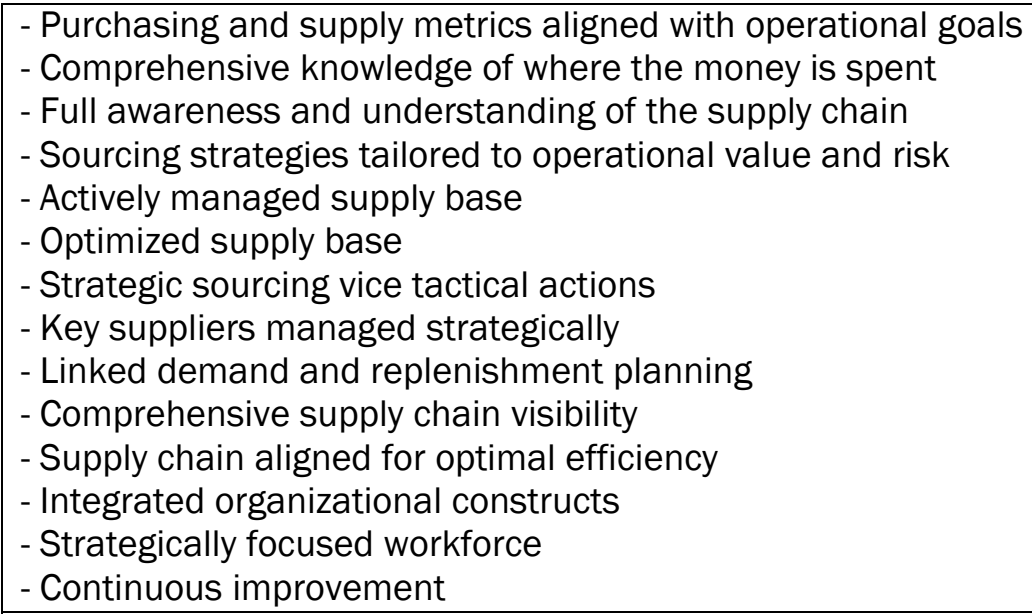

and not limited to purchase price. The most common connotation of strategic sourcing is reaping rate savings from economies of scale (i.e., consolidating requirements and leveraging spend volume; reducing the supply base and number of contracts). However, as Table 1 shows, strategic sourcing entails many additional mechanisms to generate savings. For example, one government agency reduced future demand by replacing incandescent taxiway lighting with LED lighting that lasts 20 years resulting in 60 percent less in energy costs, less contract labor to replace airfield lighting, and 50 percent lower purchase costs, saving \$2.6 million annually.

Public procurement professionals rely heavily on competition to secure fair and reasonable prices for services. However, as described above, knowledge-based services - and more importantly, their outputs - are often difficult to define. Additionally, service levels are highly variable across service providers since service levels are heavily dependent on the skills, experiences, and capabilities of the individual employees performing the work. Notwithstanding, as knowledge workers work alongside public employees, they develop a unique understanding of the agencies' organizations, processes, regulations, and information technology systems. This expertise makes switching suppliers quite costly, and potentially renders frequent competition counterproductive. This study explores these 
problems with the goal of unveiling techniques that should yield efficiencies in sourcing knowledge-based services.

\section{METHODOLOGY}

Three methods most appropriately address the four research questions. A literature review has been used to identify the relevant strategies of strategic sourcing. A spend analysis (Pandit \& Marmanis, 2008) addresses the question of what types of knowledge-based services are procured. A multiple-case study methodology (Yin, 2009) was then used to identify best practices in sourcing knowledge-based services and the most prevalent cost drivers.

Spend analysis is defined as "a tool that provides knowledge about who are the buyers, who are the suppliers, how much is being spent for what goods and services, and where are the opportunities to leverage buying power" (GAO, 2004, p. 2). It is the starting point of strategic sourcing (Pandit \& Marmanis, 2008). Spend analysis identifies targets of opportunities and current risks in the acquisition of supplies and services (Cook, Grammich, Lindenblatt, \& Moore, 2004). Spend analysis is used to develop optimal sourcing strategies, and identifies opportunities to rationalize the supply base, reduce transactions, aggregate spend, leverage spend volume, standardize requirements eliminating duplicate parts and reducing inventory, and estimate potential savings. It is also the window into compliance revealing the extent to which buying activities are not using designated contracts. Spend analysis can result in savings from two to 25 percent (Pandit \& Marmanis, 2008).

The spend analysis process is generally comprised of the following steps: (1) access all sources of spend data; (2) adopt a common classification scheme; (3) cleanse 'dirty' data where necessary; (4) classify the data; and (5) sort and analyze the data according to needed information such as the amount of funds spent, number of contract actions, number or suppliers, and number of buying offices per commodity family (Aberdeen Group, 2004). These steps were applied to one case - the United States Air Force's contract spend during fiscal year 2010. This case was selected due to the authors' access to spend data and to subject matter experts for interviews. 
The case study methodology is an appropriate method where research questions are exploratory and seek to understanding how or why events occurred. This approach is preferred when studying a contemporary phenomenon within its real life context and where the behaviors cannot be manipulated (Yin, 2009). The case study methodology involves direct observations and interviews of the subjects involved in a particular phenomenon being studied (Yin, 2009). It was appropriate for this study since a primary goal of the research has been to explain best practices (i.e., how knowledge based services are sourced), and cannot be answered through experimentation.

\section{Validity and Reliability}

Researchers must be concerned with three types of validity: 1) construct validity, which involves establishing correct operational measures for the concepts being studied; 2) internal validity, which is the establishment of causal relationships; and 3) external validity, the extent to which the study's findings can be generalized (Kerlinger \& Lee, 2000). Reliability boils down to consistency - the extent to which a study could be repeated with the same results. To ensure construct validity, multiple types of organizations were examined and individuals having first-hand experiences were interviewed (Yin, 2009). Two semi-structured interview protocols (Appendices 1 and 2) were developed to bolster reliability (Yin, 2009.), one for not-for-profit informants and the other representing the for-profit sector. To ensure content validity, two academicians reviewed the questionnaire. Additionally, a public-sector director of a knowledge-based services commodity council reviewed the questionnaire. Changes were made based on their expert advice.

\section{Data Collection}

Interview informants were identified from attendants at a supply management conference in 2012. Additionally, we identified businesses supporting the Global Research Center for Strategic Supply Management as well as representatives from the not-for-profit sector for inclusion in the interviews. We invited 83 for-profit and 16 not-for-profit contacts to participate in the research. Seven for-profit sector contacts and five not-for-profit sector contacts participated. 
The qualitative data was obtained through an examination of the relevant literature and through the conduct of semi-structured telephonic, electronic mail, and personal interviews with individuals that had first-hand knowledge with sourcing knowledge-based services. Of the 12 interviews, six conversed via email and six via phone. Interviews were recorded- then transcribed. Following the interviews, the researchers had informants review the documented responses to ensure that their responses were accurately captured. This process corroborated facts, increased the accuracy of each case study, and thereby, increased construct validity (Yin, 2009). We analyzed 114 pages of transcripts. We used an Excel spreadsheet to document the participants' answers to the respective for-profit and not-for-profit questionnaire and used this data to answer our research questions.

\section{RESULTS}

\section{Relevant Sourcing Strategies and Best Practices}

An assessment of 119 organizations across 25 industries conducted by the Global Center for Strategic Supply Management identified 22 strategic sourcing strategies (Monczka \& Peterson, 2011). (See Table 2).

TABLE 2

Sourcing Strategies and Savings Levers

\begin{tabular}{|l|l|}
\hline \multicolumn{1}{|c|}{ Sourcing Strategy } & \multicolumn{1}{c|}{ Savings Lever } \\
\hline $\begin{array}{l}\text { Engagement by corporate } \\
\text { executives and business unit } \\
\text { leaders }\end{array}$ & Goal setting and accountability \\
\hline $\begin{array}{l}\text { Vision, mission, and strategic } \\
\text { plan }\end{array}$ & Goal setting and resource allocation \\
\hline $\begin{array}{l}\text { *Commodity and supplier } \\
\text { strategy process }\end{array}$ & $\begin{array}{l}\text { Goal setting; cost driver analysis; } \\
\text { spend analysis; market intelligence; } \\
\text { opportunity assessment }\end{array}$ \\
\hline *Strategic cost management & Demand management/reduction \\
\hline $\begin{array}{l}\text { Procurement and supply } \\
\text { organization structure and } \\
\text { governance (center-led) }\end{array}$ & $\begin{array}{l}\text { Organizational alignment; goal } \\
\text { setting; resource prioritization; goal } \\
\text { setting and accountability }\end{array}$ \\
\hline
\end{tabular}


TABLE 2 (Continued)

\begin{tabular}{|c|c|}
\hline Sourcing Strategy & Savings Lever \\
\hline Human resource development & Commodity and sourcing knowledge \\
\hline Total cost of ownership (TCO) & Minimize costs \\
\hline $\begin{array}{l}\text { *Structure and maintaining the } \\
\text { supply base }\end{array}$ & $\begin{array}{l}\text { Supplier rationalization; aggregating } \\
\text { demand, then leverage spend } \\
\text { volume to reap economies of scale } \\
\text { and fewer transactions }\end{array}$ \\
\hline Measurement and evaluation & Goal setting and accountability \\
\hline $\begin{array}{l}\text { Establishing world-class } \\
\text { supplier quality }\end{array}$ & $\begin{array}{l}\text { Decrease defects, repairs, and } \\
\text { warranty costs; increase sales }\end{array}$ \\
\hline $\begin{array}{l}\text { *Supplier assessment, } \\
\text { measurement, and } \\
\text { communications; }\end{array}$ & $\begin{array}{l}\text { Continuous improvement; } \\
\text { incentives }\end{array}$ \\
\hline $\begin{array}{l}\text { *Cross-functional/location } \\
\text { teaming }\end{array}$ & $\begin{array}{l}\text { Deep commodity knowledge; } \\
\text { market intelligence }\end{array}$ \\
\hline Strategic supplier alliance & $\begin{array}{l}\text { Relational exchange; buyer and } \\
\text { supplier investments; reduce } \\
\text { duplication; reduce transaction } \\
\text { costs; goal congruence; } \\
\text { performance incentives }\end{array}$ \\
\hline $\begin{array}{l}\text { Collaborative buyer/supplier } \\
\text { development and continuous } \\
\text { improvement }\end{array}$ & $\begin{array}{l}\text { Increase competition and improve } \\
\text { quality; reduce supply risk }\end{array}$ \\
\hline $\begin{array}{l}\text { Accelerated change } \\
\text { management }\end{array}$ & $\begin{array}{l}\text { Sourcing strategy implementation } \\
\text { time }\end{array}$ \\
\hline $\begin{array}{l}\text { Supplier integration into new } \\
\text { products, services, } \\
\text { components, and development }\end{array}$ & $\begin{array}{l}\text { Eliminate duplication of effort and } \\
\text { waste; product substitution }\end{array}$ \\
\hline $\begin{array}{l}\text { Strategic insourcing/ } \\
\text { outsourcing* }\end{array}$ & Lowest-TCO provider \\
\hline $\begin{array}{l}\text { Standardization of products, } \\
\text { services, components, and } \\
\text { design specifications }\end{array}$ & $\begin{array}{l}\text { Aggregate demand/leverage } \\
\text { volume; decreased inventory and } \\
\text { transportation }\end{array}$ \\
\hline $\begin{array}{l}\text { E-sourcing and supply chain } \\
\text { strategies }\end{array}$ & $\begin{array}{l}\text { Automate processes; minimize time } \\
\text { and labor; maximize competition via } \\
\text { e-auctions; reduce inventory costs } \\
\text { by reducing procurement (i.e., } \\
\text { forecasting) lead time }\end{array}$ \\
\hline
\end{tabular}


TABLE 2 (Continued)

\begin{tabular}{|l|l|}
\hline \multicolumn{1}{|c|}{ Sourcing Strategy } & \multicolumn{1}{c|}{ Savings Lever } \\
\hline $\begin{array}{l}\text { *Global sourcing and supply } \\
\text { strategy \& low-cost regions }\end{array}$ & $\begin{array}{l}\text { Labor rate savings; transportation } \\
\text { costs; import/export costs }\end{array}$ \\
\hline $\begin{array}{l}\text { Environmentally sustainable } \\
\text { supply chain management }\end{array}$ & $\begin{array}{l}\text { Demand management; resource } \\
\text { reuse }\end{array}$ \\
\hline $\begin{array}{l}\text { Supplier integration into } \\
\text { customer order fulfillment }\end{array}$ & $\begin{array}{l}\text { Consignment inventory; eliminate } \\
\text { duplicate efforts }\end{array}$ \\
\hline
\end{tabular}

Note: *Best Practices In Knowledge-based Services

We used input from informants to answer the first two research questions - what strategic sourcing strategies are relevant to knowledge-based services, and what are the best practices? Informants were asked whether they employed these strategies during the interviews. The seven most common strategies included: (1) commodity and supplier strategy process; (2) strategic cost management/demand management; (3) supplier assessment, measurement, and communications; (4) cross-functional/location teaming; (5) strategic insourcing/outsourcing; (6) global sourcing and supply strategy and low-cost regions; and (7) contract type and outcome specification.

\section{Commodity and Supplier Strategy Process}

The most widely utilized sourcing strategy begins with conducting a spend analysis from which all other strategies flow. Eight of 12 informants track the spend within their organization. The informant from the global engineering company "employs a spend analysis tool and data cleansing service that take the spend from multiple different systems and normalize the spend for analysis". The Department of Veterans Affairs realized a \$394 million cost reduction in pharmaceutical procurement in one year after conducting a spend analysis (GAO, 2004).

\section{Strategic Cost Management}

Much like demand management, strategic cost management requires the development of strategies to identify and manage all costs and cost drivers that could be controlled, reduced, or eliminated 
pertaining to design, quality, inventory, transportation, and disposal costs associated throughout the life cycle of the product or service (Monczka \& Peterson, 2011). Demand management is one tool to that public procurement can use to involve itself early in the organization's strategic planning (i.e., resource allocation) process thereby improving the effective and efficient delivery of public services (Hinson \& McCue, 2004). Yet demand management has also been identified as a weakness in public procurement (Cox, Chicksand, \& Ireland, 2005). A careful analysis could result in the identification of a substitute material or service, consolidation of transportation assets, better inventory management procedures, or a means of recycling that could result in cost savings without sacrificing quality. One informant stated, "Whenever we scope a project, we ask if there is a way to get work done with fewer resources or hours. We are sensitive to 'over-buying' and seek to always 'right size' any purchase". Many educational institutions where instructors provide online interactive classes have realized cost savings by eliminating the physical space required to house students without sacrificing the quality of education. Public agencies could apply demand management levers such as eliminating demand, reducing quantity, simplifying specifications, reducing frequency, encouraging substitution, imposing tighter process and tracking, increasing cost awareness, and tightening policies (ATKearny, 2003).

\section{Supplier Assessment, Measurement, and Communications}

Organizations should develop metrics to evaluate a supplier's performance, strategies, and processes to gauge performance against specified objectives (Monczka \& Peterson, 2011). Presenting clearly defined performance metrics up front to a supplier can reduce the risk of sub-standard performance. One for-profit informant who works for a food production and distribution company developed a monthly scorecard to track the key performance indicators. Another for-profit informant who works for an assisted living company used a quarterly vendor review to track current clientele, sales, and subjective questions such as value the vendor is bringing to the organization, how the vendor is going to maintain its relationship with the organization, and what its IT infrastructure can support. Both informants performed these evaluations face to face with the supplier so that issues could be resolved quickly with little interference from day-to-day operations. 


\section{Cross-Functional/Location Teaming}

Before making large or complex purchasing decisions, an organization should attempt to gather expert personnel from appropriate departments to work in tandem to develop purchasing strategies (Monczka \& Peterson, 2011). The USAF uses integrated product and process development teams to gather the correct personnel in the planning and purchasing of major acquisitions such as aircraft, weapon systems, and satellite programs. Additionally, the USAF developed commodity councils for commodities and services that are purchased by many activities across the entire department to aid in strategic sourcing.

\section{Structure and Maintaining the Supply Base}

Many organizations have multiple buying offices that purchase the same services at different locations. Additionally, organizations inadvertently use multiple contracts for the same service. Organizations that consolidate multiple contracts within the same buying office or across multiple buying offices can avoid transaction costs (e.g., source selection effort and associated procurement leadtime, payment processing, closeouts, etc.) and often obtain a lower price from economies of scale. One informant stated, "When a category is sourced for the first time, we do extensive research into our supplier database to determine where all of the usage is currently occurring. This allows us to coordinate all the key users of the services and leverage the spend across the company."

\section{Strategic Insourcing/Outsourcing}

Before organizations make any purchasing decisions, they should "evaluate internal capabilities, competencies, and capacity verses external sources and capabilities to identify opportunities to better focus on core competencies, improve product/service differentiation, and develop and sustain competitive advantage" (Monczka \& Peterson, 2011, p. 50). Organizations that wish to outsource should ensure that they retain the knowledge of the position they are outsourcing, as well as understand how to manage the outsourced position. One for-profit informant stated, "We always compare the cost of insourcing verses outsourcing when we are determining a sourcing strategy for services". Another for-profit informant stated, "It depends on the specific services and application on a project or with 
the corporate entity. The method is not characterized by preference". A cost benefit analysis between federal and contract employees in 35 employment categories revealed that on average, contracted professional services employees earn 1.83 times more in total compensation as opposed to a federal employees and in 33 of the 35 categories the federal employees were less expensive (POGO, 2013).

\section{Global Sourcing and Supply Strategy and Low-Cost Regions}

One buyer of legal services used the strategy of moving expensive professional labor (i.e., attorneys) to domestic low cost regions. Contract employees working virtually in the Southeast, for instance, have lower salaries than do those located in New York. This practice is confirmed by similar findings by Hancock and Ellsworth (2013).

Our informants identified one cost-saving best practice for knowledge-based services that is not a recognized strategic sourcing strategy. Rather, it pertains to contract type and the outcome of the service. Commonly, professional services are contracted as time and materials or labor-hour contracts whereby the buyer simply buys the professional's time. One informant advised that in buying legal services, he moved to specified, fixed-price deliverables, where possible. The USAF also identified this strategy as a future prospect for savings.

\section{Types of Procured Knowledge-based Services}

In order to identify the typical knowledge-based services procured, we conducted a spend analysis of USAF spend data from fiscal year 2010. The USAF FY2010 spend data included 147,222 contract actions totaling $\$ 63.03$ billion, with acquisition of services being a major portion of this expenditure. The USAF obligated $\$ 25.85$ billion acquiring services, which was $41.02 \%$ of the total USAF spend. Of 147,222 contract actions, 54,448 were initial awards, delivery orders and task orders accounting for $\$ 22.13$ billion, while the remaining 92,774 contract actions were modifications to existing contracts, accounting for $\$ 40.90$ billion. Knowledge-based services in FY2010 accounted for $\$ 9.77$ billion, which was $15.5 \%$ of the total USAF spend and $37.82 \%$ of the total spend for services. Of the total spend of $\$ 9.77$ billion on knowledge-based services, $\$ 3.59$ billion was obligated on initial awards, delivery orders and task orders, whereas the remaining $\$ 6.18$ billion funded modifications. 
The USAF conducted all acquisitions of supplies and services in FY2010 through 245 different buying offices. Of the buying offices, 209 were involved in procuring knowledge-based services. Involvement of more than 80 percent of the total buying offices in the acquisition of knowledge-based services may deny the USAF opportunities to reduce transaction costs. In addition, fragmented buying and duplication of effort in purchasing knowledge-based services may also preclude the government from capturing tacit knowledge to achieve efficiencies. One key tenet of strategic sourcing - developing deep category expertise - is foregone by fragmented buying.

In FY2010, 18,819 different contractors undertook business with the USAF, of which 3,292 were involved in provision of knowledgebased services. This statistic highlights the opportunity to realize cost savings in terms of transactional costs by reducing the number of contracts, task orders, and suppliers.

The USAF acquired knowledge-based services through 27,291 contract actions that included 6,677 initial awards, delivery orders and task orders. Knowledge-based services contract actions accounted for $18.53 \%$ of the total contract actions and $12.26 \%$ of the initial awards, delivery orders and task orders.

Most of the spending on knowledge-based services was concentrated in professional, administrative, and management services, with a total spend of $\$ 8.32$ billion, representing $13.21 \%$ of the total spend for FY2010 and $32.19 \%$ of spend on services. We focused on five sub-categories selected based on the majority of spend. These five sub-categories comprised a total spend of $\$ 5.26$ billion, which is $8.35 \%$ of the total spending, $20.35 \%$ of service spending, and $53.82 \%$ of knowledge-based service spending for FY2010. Table 3 details the contract awards in these five subcategories.

Promoting and creating a competitive environment can result in substantial cost savings, and as seen below in Table 4, is a preferred technique among our sample of informants. However, the spend data for the knowledge-based services highlights a heavy reliance on sole source contracts. Recently, the GAO identified a need for increased competition in DoD procurement (GAO, 2013). 
TABLE 3

Spend Detail of Selected Product Service Codes

\begin{tabular}{|l|c|c|c|c|c|}
\hline \multicolumn{1}{|c|}{ Description } & \multicolumn{2}{|c|}{$\begin{array}{c}\text { Number of } \\
\text { Contract Actions }\end{array}$} & $\begin{array}{c}\text { Obligation } \\
\text { (\$ million) }\end{array}$ & $\begin{array}{c}\text { Buying } \\
\text { Offices }\end{array}$ & Suppliers \\
\cline { 2 - 5 } & Total* & $\begin{array}{c}\text { Initial } \\
\text { awards, } \\
\text { D0/TOs }\end{array}$ & & & \\
\hline $\begin{array}{l}\text { Program } \\
\text { Management / } \\
\text { Support Services }\end{array}$ & 2,855 & 651 & 765.7 & 95 & 277 \\
\hline $\begin{array}{l}\text { Systems Engineering } \\
\text { Services }\end{array}$ & 3,136 & 544 & $1,911.4$ & 79 & 209 \\
\hline $\begin{array}{l}\text { Engineering and } \\
\text { Technical Services }\end{array}$ & 3,619 & 788 & $1,280.0$ & 122 & 364 \\
\hline $\begin{array}{l}\text { Logistics Support } \\
\text { Services }\end{array}$ & 823 & 160 & $1,121.1$ & 62 & 112 \\
\hline $\begin{array}{l}\text { Contract, } \\
\text { Procurement and } \\
\text { Acquisition Support } \\
\text { Services }\end{array}$ & 643 & 17 & 184.6 & 21 & 37 \\
\hline
\end{tabular}

Note: * Includes modifications.

TABLE 4

Sole Source Contracts

\begin{tabular}{|l|c|c|c|}
\hline \multicolumn{1}{|c|}{ Description } & $\begin{array}{c}\text { Contract } \\
\text { Actions* }\end{array}$ & $\begin{array}{c}\text { Sole Source } \\
\#\end{array}$ & $\begin{array}{c}\text { Sole Source } \\
\%\end{array}$ \\
\hline $\begin{array}{l}\text { Program Management / } \\
\text { Support Services }\end{array}$ & 651 & 141 & $21.65 \%$ \\
\hline Systems Engineering Services & 544 & 227 & $41.72 \%$ \\
\hline $\begin{array}{l}\text { Engineering and Technical } \\
\text { Services }\end{array}$ & 788 & 309 & $39.21 \%$ \\
\hline Logistics Support Services & 160 & 63 & $39.37 \%$ \\
\hline $\begin{array}{l}\text { Contract, Procurement, and } \\
\text { Acquisition Support Services }\end{array}$ & 17 & 8 & $47.05 \%$ \\
\hline Total & 2,160 & 748 & $34.62 \%$ \\
\hline
\end{tabular}

Note: *Excludes modifications. 
Of the 748 sole source contract actions, 250 contracts were "not available for competition" while the remaining 498 contracts were "not competed". "Not available for competition" were those contracts which are set aside to satisfy socio-economic goals or mandatory source of supply. Four-hundred and ninety eight contracts in the category of not being competed, represent $66.57 \%$ of all sole sourced knowledge-based contracts in our selected five categories, which depicts a possible opportunity for supplier development. Supplier development could be manifested in two ways. First, if there is truly only one source - perhaps due to a unique capability or intellectual property rights, the buyer could work with the supplier to maximize quality and reduce costs. Second, stimulating competition in solesource knowledge-based contracts presents another opportunity for savings. In this case, alternative sources could be developed to infuse competition in the market.

One trend in government sourcing that appears to be incongruent with strategic sourcing pertains to reactions to bid protests and the threat of bid protests. Bid protests are loathed in public sourcing likely more so than inefficiency. Often, agencies will award umbrella contracts (e.g., indefinite quantity/indefinite delivery contracts or blanket purchase agreements) to all offerors in order to avoid a bid protest. This results in excess contracts and excess contractors such as the U.S. Navy's Seaport-e program that awarded over 1,800 contracts (NAVSEA, 2013) for knowledge-based services. Notwithstanding, in reaction to bid protests received, agencies often take corrective action by awarding umbrella contracts to all offerors. For example, in 2009, the U.S. Army awarded 7 contracts for knowledge-based services, but later terminated these contracts and awarded 18 contracts, one to each technically acceptable offeror, in response to multiple bid protests (U.S. Court of Federal Claims, 2010). While this decision may be a simple means to alleviate the bid protest at hand, multiple awards result in excess contracts, excess contractors, excess contract administration, and added effort in future task order competitions.

Another long-standing practice in public sourcing is socioeconomic set asides. The federal 8(a) program allows agencies to contract directly (i.e., sole source) with small disadvantaged businesses. Buyers are attracted to this program in order to save procurement lead time by avoiding a lengthy source selection - that 
also invites bid protest risk. However, time savings may come at the expense of excess costs where sole source negotiations fail to match market efficiencies afforded by competition. While increased competition will likely effectively contribute to increased efficiency, many knowledge-based services are constrained to a sole source. In these cases, alternative efficiency strategies are necessary, which may be revealed in the analysis of cost drivers.

The USAF used a variety of contract types while procuring knowledge-based services. Table 5 depicts the breakdown of 2,160 contracts in the selected five categories by contract type. In 45.69\% of the contract actions, the contractor assumed liability for cost

TABLE 5

Knowledge-based Service Contract Types

\begin{tabular}{|l|c|c|}
\hline \multicolumn{1}{|c|}{ Contract Type } & Number & Percentage \\
\hline Fixed-price (FP) & 987 & $45.69 \%$ \\
\hline Cost-reimbursement (CR) & 868 & $40.18 \%$ \\
\hline Time-and-material (T\&M) & 275 & $12.73 \%$ \\
\hline Labor hour (LH) & 30 & $1.38 \%$ \\
\hline
\end{tabular}

overruns, whereas the remaining $54.31 \%$ of the contract actions placed most cost risk on the government.

\section{Cost Drivers}

The final research question addresses cost drivers of knowledgebased services. In addition to cost drivers identified by the twelve informants, we sampled 100 USAF contracts from the five categories listed in Table 4 - 25 each. We examined each statement of work and line item descriptions to discern the service outcomes acquired (e.g., permanent or temporary on-site support staff labor, technical report, study, analyses, etc.).

The primary cost drivers identified by informants were labor hours, labor rates, expertise, complexity of task, and capabilities, as shown in Table 6. Targeting rate savings (e.g., salaries and overhead costs) alone leaves most cost drivers associated with knowledgebased service untouched. One informant commented: "It is the savings here is less in rate and more in terms of demand management." Thus, new strategies other than competition and 
TABLE 6 Cost Drivers

\begin{tabular}{|c|c|c|c|}
\hline $\begin{array}{c}\text { Private } \\
\text { Sector } \\
\text { Informant }\end{array}$ & Outcomes & Cost Drivers & Cost Mitigation Strategies \\
\hline $\begin{array}{l}\text { Assisted } \\
\text { Living } \\
\text { Services } \\
\text { Company }\end{array}$ & $\begin{array}{l}\text { Sales } \\
\text { enhance- } \\
\text { ment; } \\
\text { resident } \\
\text { satisfaction; } \\
\text { IT support }\end{array}$ & $\begin{array}{l}\text { Legal fee } \\
\text { variation by } \\
\text { location; } \\
\text { overhead } \\
\text { costs; profit } \\
\text { margins }\end{array}$ & $\begin{array}{l}\text { Apply TCO analysis; insource; } \\
\text { budget approval; use interns; } \\
\text { competition; define } \\
\text { measurable results; supplier } \\
\text { performance evaluation; } \\
\text { central buying; contract } \\
\text { consolidation; negotiation; } \\
\text { reverse auctions; buy } \\
\text { deliverables vs. time }\end{array}$ \\
\hline $\begin{array}{l}\text { Domestic } \\
\text { and Inter- } \\
\text { national } \\
\text { Relocation } \\
\text { Company }\end{array}$ & $\begin{array}{l}\text { Serviceable } \\
\text { actions }\end{array}$ & Labor hours & $\begin{array}{l}\text { Competitive bidding; market } \\
\text { research; supplier } \\
\text { performance evaluation; } \\
\text { centralized buying; incentive } \\
\text { contract }\end{array}$ \\
\hline $\begin{array}{l}\text { Petroleum } \\
\text { Managem- } \\
\text { ent } \\
\text { Company }\end{array}$ & $\begin{array}{l}\text { Piping \& } \\
\text { instrumenta } \\
\text {-tion } \\
\text { Diagram; } \\
\text { alignment } \\
\text { sheets for } \\
\text { pipelines }\end{array}$ & $\begin{array}{l}\text { Labor hours; } \\
\text { labor rates; } \\
\text { overhead; } \\
\text { profit }\end{array}$ & $\begin{array}{l}\text { Competitive bidding; buy } \\
\text { deliverables vs. time; TCO } \\
\text { analysis }\end{array}$ \\
\hline $\begin{array}{l}\text { Food } \\
\text { Production } \\
\text { and } \\
\text { Distribution } \\
\text { Company }\end{array}$ & $\begin{array}{l}\text { Technical } \\
\text { report; } \\
\text { research; } \\
\text { staff } \\
\text { support } \\
\text { labor; } \\
\text { education; } \\
\text { training; } \\
\text { analysis; } \\
\text { expertise; } \\
\text { advice; } \\
\text { presenta- } \\
\text { tions; white } \\
\text { paper }\end{array}$ & $\begin{array}{l}\text { Labor hours } \\
\text { driven by } \\
\text { expertise } \\
\text { level of } \\
\text { personnel }\end{array}$ & $\begin{array}{l}\text { Well defined requirement in } \\
\text { SOW outlining } \\
\text { deliverables; budget; } \\
\text { requirement of detailed bids; } \\
\text { competition; negotiation; } \\
\text { supplier performance } \\
\text { evaluation; control changes; } \\
\text { TCO analysis; a supplier's } \\
\text { ability to reduce costs during } \\
\text { source selection evaluated; } \\
\text { off-shoring; centralized } \\
\text { buying; reverse auctions; } \\
\text { spend analysis; demand } \\
\text { management }\end{array}$ \\
\hline
\end{tabular}


TABLE 6 (Continued)

\begin{tabular}{|c|c|c|c|}
\hline $\begin{array}{c}\text { Private } \\
\text { Sector } \\
\text { Informant }\end{array}$ & Outcomes & $\begin{array}{c}\text { Cost } \\
\text { Drivers }\end{array}$ & Cost Mitigation Strategies \\
\hline $\begin{array}{l}\text { Global } \\
\text { Engineering } \\
\text { Company }\end{array}$ & $\begin{array}{l}\text { Scope } \\
\text { defined in } \\
\text { the contract }\end{array}$ & \begin{tabular}{|l|} 
Level of \\
complexity
\end{tabular} & $\begin{array}{l}\text { Competitive bidding; well } \\
\text { defined SOW; center-led } \\
\text { procurement; careful cost } \\
\text { and progress monitoring; } \\
\text { change management; TCO } \\
\text { analysis; share-in-savings } \\
\text { contracts; market research; } \\
\text { knowledge management } \\
\text { system; strategic sourcing; } \\
\text { spend analysis; supplier } \\
\text { rationalization; buy } \\
\text { deliverables vs. time }\end{array}$ \\
\hline $\begin{array}{l}\text { Acquisition } \\
\text { Learning } \\
\text { Solutions } \\
\text { Company }\end{array}$ & $\begin{array}{l}\text { Education; } \\
\text { training; } \\
\text { expertise; } \\
\text { advice; } \\
\text { technical } \\
\text { reports }\end{array}$ & $\begin{array}{l}\text { Travel; } \\
\text { training } \\
\text { materials } \\
\text { kept up-to- } \\
\text { date }\end{array}$ & $\begin{array}{l}\text { Forecasting; managing } \\
\text { personnel and training } \\
\text { material; demand } \\
\text { management }\end{array}$ \\
\hline $\begin{array}{l}\text { Global } \\
\text { Payment } \\
\text { Processing } \\
\text { Company }\end{array}$ & $\begin{array}{l}\text { Technical } \\
\text { reports; } \\
\text { research; } \\
\text { staff support; } \\
\text { education; } \\
\text { training; } \\
\text { analysis; } \\
\text { expertise, } \\
\text { advice, } \\
\text { presentation, } \\
\text { white paper }\end{array}$ & $\begin{array}{l}\text { Labor } \\
\text { rates; } \\
\text { lead-time; } \\
\text { competitio } \\
\text { n }\end{array}$ & $\begin{array}{l}\text { Proper planning; accurate } \\
\text { Sow; review of historical } \\
\text { usage; competitive } \\
\text { bidding; demand } \\
\text { management; commodity } \\
\text { councils; spend approvals; } \\
\text { standardization; TCO } \\
\text { analysis; supplier } \\
\text { performance evaluation; } \\
\text { requirement of tacit } \\
\text { knowledge transfer in the } \\
\text { SOW; spend analysis; } \\
\text { aggregate \& leverage spend; } \\
\text { e-sourcing }\end{array}$ \\
\hline
\end{tabular}


TABLE 6 (Continued)

\begin{tabular}{|c|c|c|c|}
\hline $\begin{array}{c}\text { Private } \\
\text { Sector } \\
\text { Informant }\end{array}$ & Outcomes & Cost Drivers & Cost Mitigation Strategies \\
\hline \multicolumn{4}{|c|}{ Public Sector Informant } \\
\hline $\begin{array}{l}\text { U. S. } \\
\text { Department } \\
\text { of Energy }\end{array}$ & $\begin{array}{l}\text { Technical } \\
\text { reports; } \\
\text { research; } \\
\text { staff support; } \\
\text { education; } \\
\text { training; } \\
\text { analysis; } \\
\text { expertise; } \\
\text { advice; } \\
\text { presentation; } \\
\text { white paper }\end{array}$ & $\begin{array}{l}\text { Time; need; } \\
\text { risk; urgency; } \\
\text { complexity; } \\
\text { criticality } \\
\end{array}$ & $\begin{array}{l}\text { Having the right } \\
\text { management; TCO } \\
\text { analysis; competition; } \\
\text { market research }\end{array}$ \\
\hline $\begin{array}{l}\text { U.S. } \\
\text { Educational } \\
\text { Institution }\end{array}$ & $\begin{array}{l}\text { Technical } \\
\text { reports; } \\
\text { research; } \\
\text { staff support; } \\
\text { education; } \\
\text { training; } \\
\text { analysis; } \\
\text { expertise; } \\
\text { advice; } \\
\text { presentation; } \\
\text { white paper }\end{array}$ & $\begin{array}{l}\text { Labor hours; } \\
\text { labor rates; } \\
\text { position } \\
\text { description } \\
\text { of } \\
\text { personnel }\end{array}$ & $\begin{array}{l}\text { Accurately described } \\
\text { needs; } \\
\text { competitive bidding; } \\
\text { sound analysis of } \\
\text { proposals }\end{array}$ \\
\hline $\begin{array}{l}\text { U.S. Military } \\
\text { Department } \\
\# 1\end{array}$ & $\begin{array}{l}\text { Technical } \\
\text { reports; } \\
\text { research; } \\
\text { staff support; } \\
\text { education; } \\
\text { training; } \\
\text { analysis; } \\
\text { expertise, } \\
\text { advice, } \\
\text { presentation, } \\
\text { white paper }\end{array}$ & \begin{tabular}{|l} 
Inability to \\
identify due \\
to \\
lack of \\
personnel \\
and \\
expertise
\end{tabular} & $\begin{array}{l}\text { Proper lead-time allowed } \\
\text { for defined requirement; } \\
\text { competitive bidding; total } \\
\text { cost realism and } \\
\text { reasonableness analysis }\end{array}$ \\
\hline
\end{tabular}


TABLE 6 (Continued)

\begin{tabular}{|l|l|l|l|}
\hline $\begin{array}{c}\text { Private } \\
\text { Sector } \\
\text { Informant }\end{array}$ & Outcomes & Cost Drivers & Cost Mitigation Strategies \\
\hline $\begin{array}{l}\text { U.S. Military } \\
\text { Department } \\
\text { \#2 }\end{array}$ & $\begin{array}{l}\text { Technical } \\
\text { reports; } \\
\text { Research; } \\
\text { staff support; }\end{array}$ & $\begin{array}{l}\text { Labor rates; } \\
\text { time }\end{array}$ & $\begin{array}{l}\text { Consolidate requirements; } \\
\text { demand management; } \\
\text { negotiated price; captured } \\
\text { tacit knowledge enabling } \\
\text { reapplication }\end{array}$ \\
& $\begin{array}{l}\text { training; } \\
\text { Analysis; } \\
\text { expertise; } \\
\text { advice; } \\
\text { presentation; } \\
\text { white paper; } \\
\text { cost analysis } \\
\text { reports }\end{array}$ & & \\
& $\begin{array}{l}\text { Temporary } \\
\text { services/ } \\
\text { staffing; } \\
\text { installation } \\
\text { support } \\
\text { services }\end{array}$ & $\begin{array}{l}\text { Timing (FY } \\
\text { end); labor } \\
\text { rates; labor } \\
\text { hours }\end{array}$ & $\begin{array}{l}\text { Buying of deliverables vs. } \\
\text { time; scrutinized contract } \\
\text { rates vs. contractor } \\
\text { employees' skills }\end{array}$ \\
\hline $\begin{array}{l}\text { U.S. Military } \\
\text { Department } \\
\text { \#3 }\end{array}$ & \\
\hline
\end{tabular}

demand aggregation appear warranted. Strategies must fundamentally alter the requirement without compromising the outcome. This is achieved through demand management activities such as substitution, checking existing inventories, and alternative work processes. As such, it is posited that:

$P_{1}$ : When sourcing knowledge-based service, demand management strategies will result in greater efficiency than will rate or processoriented strategies.

Turning back to knowledge management theory, scholars explicate the importance of sharing knowledge. In large organizations, sharing and storing knowledge could alleviate the need for [re]purchasing the same knowledge or application thereof. However, rarely is there an incentive to invest in the infrastructure to facilitate knowledge management. Public policy can help in this 
regard by creating duties to better capture, diffuse, store, and reuse knowledge. Such efforts could have the effect of reducing future demand by eliminating duplicate contracts and by building wisdom among employees. Therefore, we posit that:

$\mathrm{P}_{2}$ : Public organizations with a procured knowledge management policy will achieve greater efficiency in sourcing knowledge-based service than those without such a policy.

Some scholars also recommend converting tacit knowledge to explicit knowledge. In cases where this conversion is possible, others must know what knowledge is available and where to find it. Here, practices of physical inventory management might be instructive that is, treating the procured knowledge as property. This practice will aid in finding and accessing procured knowledge and infuse accountability for reuse prior to re-purchase. As such, it is posited that:

$\mathrm{P}_{3}$ : Treating procured knowledge as owned intellectual property rather than as a one-time service event will result in greater efficiency.

An alarming phenomenon is reflected in one informant's comment: "we actually found that a lot of the spend is where an organization is spending money through [KBS]-and we found this to be quite prevalent-to cover inadequacies in their organic workforce both in terms of numbers and in terms of skillsets." Contracting may be a faster means to desired outcomes rather than to invest in the organic workforce to address capability deficiencies or gaps. Thus, policies that force investment in building organic capabilities might mitigate demand for procured knowledge-based services.

\section{DISCUSSION}

In an effort to explore whether and how the public sector can improve efficiency in sourcing knowledge-based services, four research questions were posed to discern: (1) strategic sourcing strategies relevant to knowledge-based services, (2) best practices in sourcing knowledge-based services, (3) the common types of knowledge-based services procured, and (4) the major cost drivers of those services. 


\section{Managerial Implications}

Through a review of the literature for best practices in procuring knowledge-based services, a review of knowledge management theory, and a review of strategic sourcing strategies, this research offers a rich set of 21 specific, actionable practices that could result in improved efficiencies in sourcing knowledge-based services (Table 7). The practices are oriented toward the three types of savings rate, process, and demand. As is evident, there appears to be more potential for savings by applying demand management strategies rather than rate or process-focused strategies. What is also apparent is a glaring need for a policy governing first the purchase of knowledge, then the management of purchased knowledge. Thus far, public policy has ignored the uniqueness of knowledge-based services by treating them as any other service.

TABLE 7

Recommendations for Improving Efficiencies in Procuring Knowledgebased Services

\begin{tabular}{|l|l|l|}
\hline Recommendation & $\begin{array}{l}\text { Type of } \\
\text { Savings }\end{array}$ \\
\hline 1. & $\begin{array}{l}\text { Convert contract support personnel to civil service } \\
\text { (insource). Applicable to long-standing services } \\
\text { based on history and projected need (e.g., staff } \\
\text { support). New requirements required to be } \\
\text { performed by new hires that are temporary or term } \\
\text { positions before permanent. }\end{array}$ & $\begin{array}{l}\text { Rate; } \\
\text { Demand } \\
\text { manage- } \\
\text { ment }\end{array}$ \\
\hline 2. & $\begin{array}{l}\text { Prohibit price analysis based on General Service } \\
\text { Administration (GSA) rates. This avoids artificial } \\
\text { competition based on inflated rates. }\end{array}$ & Rate \\
\hline 3. & $\begin{array}{l}\text { Require 3+ rounds of price/cost-based negotiations } \\
\text { in all source selections (including task orders). }\end{array}$ & Rate \\
\hline 4. & $\begin{array}{l}\text { Examine and avoid surcharges associated with } \\
\text { using inter-agency contracts. Set ceilings on } \\
\text { individual surcharges and negotiate the rates. }\end{array}$ & Rate \\
\hline 5. & $\begin{array}{l}\text { Increase competition. Set a statutory goal of 75\% } \\
\text { competition rate for KBS. Conduct root cause } \\
\text { analysis on 100\% of prior years' sole source spend. } \\
\text { Mitigate causes (e.g., data rights, urgency due to } \\
\text { poor planning, etc.). }\end{array}$ & Rate \\
\hline
\end{tabular}


TABLE 7 (Continued)

\begin{tabular}{|c|c|c|}
\hline & Recommendation & $\begin{array}{l}\text { Type of } \\
\text { Savings }\end{array}$ \\
\hline 6. & $\begin{array}{l}\text { Convert T\&M and labor-hour contracts to FFP } \\
\text { and force requiring activities to specify } \\
\text { deliverables in advance. }\end{array}$ & Rate \\
\hline 7. & $\begin{array}{l}\text { Conduct root cause analysis explaining the } \\
\text { explosion of contracted KBS. Mitigate causes. }\end{array}$ & $\begin{array}{l}\text { Demand } \\
\text { management }\end{array}$ \\
\hline 8. & $\begin{array}{l}\text { Enforce the prohibition on contracting inherently } \\
\text { governmental functions in order to avoid } \\
\text { conflicts of interest. }\end{array}$ & $\begin{array}{l}\text { Demand } \\
\text { management }\end{array}$ \\
\hline 9. & $\begin{array}{l}\text { Incorporate requirements in contracts for } \\
\text { contractors to generate cost savings ideas. } \\
\text { Make this part of the evaluation factors for } \\
\text { award, contract deliverables, award fee } \\
\text { determinations, and part of past performance } \\
\text { evaluations. }\end{array}$ & $\begin{array}{l}\text { Rate; } \\
\text { Demand } \\
\text { management; } \\
\text { Process }\end{array}$ \\
\hline 10. & $\begin{array}{l}\text { Make contracted KBS employees count against } \\
\text { an organization's unit manning } \\
\text { document/personnel ceiling. }\end{array}$ & $\begin{array}{l}\text { Demand } \\
\text { management }\end{array}$ \\
\hline 11. & $\begin{array}{l}\text { Set statutory limit on the maximum ratio of } \\
\text { contractor support personnel-to-government } \\
\text { employees for each function or unit. }\end{array}$ & $\begin{array}{l}\text { Demand } \\
\text { management }\end{array}$ \\
\hline 12. & $\begin{array}{l}\text { Set policy that HR/civilian personnel must } \\
\text { approve statements of work prior to solicitation. } \\
\text { HR will compare work to civilian core } \\
\text { documents/personnel descriptions to ensure } \\
\text { existing employees can't perform the work. }\end{array}$ & $\begin{array}{l}\text { Demand } \\
\text { management }\end{array}$ \\
\hline 13. & $\begin{array}{l}\text { For consultants, require a process for } \\
\text { consultants to transfer their tacit knowledge to } \\
\text { government employees. Make the transfer a } \\
\text { contract requirement, and evaluate how an } \\
\text { offeror will do this during source selection. This } \\
\text { will prevent contracting for the same or similar } \\
\text { analysis in the future. }\end{array}$ & $\begin{array}{l}\text { Demand } \\
\text { management }\end{array}$ \\
\hline 14. & $\begin{array}{l}\text { Require contractors to convert tacit knowledge to } \\
\text { explicit knowledge as a contractual requirement. }\end{array}$ & $\begin{array}{l}\text { Demand } \\
\text { management }\end{array}$ \\
\hline 15. & $\begin{array}{l}\text { Measure and minimize government employee } \\
\text { and contractor employee turnover. }\end{array}$ & $\begin{array}{l}\text { Demand } \\
\text { management }\end{array}$ \\
\hline
\end{tabular}


TABLE 7 (Continued)

\begin{tabular}{|c|c|c|}
\hline & Recommendation & $\begin{array}{l}\text { Type of } \\
\text { Savings }\end{array}$ \\
\hline 16. & $\begin{array}{l}\text { Develop a distinct certification for managing } \\
\text { contracted KBS. }\end{array}$ & $\begin{array}{l}\text { Rate; } \\
\text { Demand } \\
\text { management; } \\
\text { Process }\end{array}$ \\
\hline 17. & $\begin{array}{l}\text { Set a contracted knowledge management policy. } \\
\text { Treat procured knowledge as purchased } \\
\text { inventory. Store it in a central data warehouse. } \\
\text { Require that all deliverables (e.g., presentations, } \\
\text { technical reports, studies, analyses, etc.) be } \\
\text { posted to the central repository. Know what } \\
\text { knowledge is on hand. Make it simple to find } \\
\text { and accessible. Reuse it. Prohibit [re]contracting } \\
\text { for the same knowledge. }\end{array}$ & $\begin{array}{l}\text { Demand } \\
\text { management }\end{array}$ \\
\hline 18. & $\begin{array}{l}\text { Conduct a spend analysis of prior } 3 \text { years' spend } \\
\text { for KBS. Find overlapping and duplicate } \\
\text { contracts for the same KBS. Eliminate this } \\
\text { possibility in the future by standing up } \\
\text { commodity councils. }\end{array}$ & $\begin{array}{l}\text { Demand } \\
\text { management }\end{array}$ \\
\hline 19. & $\begin{array}{l}\text { Create and maintain a directory of government } \\
\text { and contractor personnel who were involved in } \\
\text { contracting for, managing, and performing each } \\
\text { KBS. }\end{array}$ & Process \\
\hline 20. & $\begin{array}{l}\text { Plot each contracted KBS on the material } \\
\text { positioning matrix (Kraljic, 1983), then apply } \\
\text { appropriate sourcing strategy per the criticality of } \\
\text { the service and the availability of supply. }\end{array}$ & $\begin{array}{l}\text { Rate; } \\
\text { Demand } \\
\text { management; } \\
\text { Process }\end{array}$ \\
\hline 21. & $\begin{array}{l}\text { Institute an acquisition review board prior to } \\
\text { budget approvals to validate needs and to } \\
\text { determine there are no alternatives to } \\
\text { procurement to satisfy needs. }\end{array}$ & $\begin{array}{l}\text { Demand } \\
\text { management }\end{array}$ \\
\hline
\end{tabular}

\section{Theoretical Implications}

This review of purchasing practices in knowledge-based services across multiple cases illuminates one role of theory, and suggests necessary and useful refinements to theory. First, this research is an 
exemplar that theory enlightens management (Van de Ven, 1989). The practice of sourcing knowledge-based services has thus far overlooked the practical value of applying knowledge management theory. Specifically, acquisition teams stand to improve the usage of procured knowledge in order to prevent purchasing the same knowledge in the future by the same or different agencies. They can do this by inventorying the procured knowledge in cases where it can be made explicit. Where procured knowledge cannot be made explicit, a directory of internal and external experts can be a resource to those in need.

Secondly, this research suggests a refinement to stakeholder theory in a public context. "Stakeholder theory argues that every legitimate person or group participating in the activities of a firm does so to obtain benefits" (Kern, Moser, Sundaresan, \& Hartmann, 2011, p. 123). The theory holds that the way in which stakeholders are managed affects financial performance (Laplume, Sonpar, \& Litz, 2008). Stakeholders are "any group or individual who can affect or is affected by the achievement of the organization's objectives" (Freeman, 1984, p. 46). In government sourcing, securing a fair and reasonable price (i.e., not over-paying) and avoiding waste (i.e., not over-buying) are requisite duties, largely oriented toward the taxpaying public stakeholders. Meeting end user needs is also a key goal of different stakeholders - the internal customers. Often, tradeoffs are made where these goals conflict. In these cases, how do sourcing professionals decide which stakeholder to satisfy the most? This research suggests that stakeholder theory applied in a public context should consider proximity of the stakeholder in determining which stakeholder to prioritize.

\section{Study Limitations and Future Research Directions}

This research is not without limitations. First, the spend analysis and interviews were restricted to federal public agencies, mostly defense. The spend profile likely differs from that of other agencies. Additionally, the spend data - like all spend data - contained coding errors. We did not endeavor to investigate and correct the coding of 147 thousand transactions. Second, the analyses are based on a small convenient sample of informants. Although informants represented both for-profit and not-for-profit sectors, some best practices may be omitted due to the small sample. 
From this study emerged five potential areas for future research. First, the presence of a standard taxonomy has the ability to streamline a complicated spend portfolio. Services spend can be classified into six categories using product-service codes (OUSD, 2010b). However, there is no standard taxonomy of the deliverables (i.e., outcomes) of purchased knowledge-based services which limits a clear and precise understanding of the true outcomes being purchased. Knowledge-based outcomes could be manifested in time and expertise continuously or periodically onsite, technical reports, discrete analyses, presentations, white papers, specifications and drawings, or studies. Each outcome could be sourced and managed differently in order to reap rate, process, and demand-based savings. Thus, future research should develop a taxonomy for deliverables in order to (1) query a database for like deliverables and (2) unveil true cost drivers and appropriate sourcing strategies to mitigate the cost drivers. Additionally, future research is needed to understand the root causes of the rapid growth of procured knowledge-based services. Future research could also explore the large proportion of sole sourced contracts for knowledge-based services. Since this research is exploratory, future research could test the preliminary propositions identified herein. Finally, future research could apply the methodology employed herein to different categories of services to seek rate, process, and demand-based efficiencies. Regardless of direction taken, knowledge-based services appear to be a fruitful, and thus worthwhile, area for public procurement research.

\section{ACKNOWLEDGEMENTS}

The authors would like to thank Muhammad Qureshi, Mohammad Syed, and Brian Welch for their professionalism, tenacity, and expertise in conducting this research. The authors also thank the three reviewers and the editor for their insights used to improve the manuscript.

\section{REFERENCES}

Aberdeen Group, Inc. (2004). Best Practices in Spending Analysis: Cure for a Corporate Epidemic. Boston, MA: Author. 
Air Force Audit Agency (2010, June 29). Commodity Council Management. (Audit Report F2010-0004-FC1000). Washington, DC: Author.

Anderson, M. G., \& Katz, P. B. (1998). "Strategic Sourcing." International Journal of Logistics Management, 9(1): 1-13.

Apte, A., Apte, U. M., \& Rendon, R. G. (2011). "Services Supply Chain in the United States Navy: An Empirical Study of Current Management Practices." Journal of Public Procurement, 11(4): 538-562.

ATKearney (2003). Demand Management: Changing the Way Organizations Acquire Goods and Services. [On-line]. Available at http://www.atkearneypas.com/knowledge/publications/2004/D emand_Management_S.pdf. [Retrieved August 1, 2013].

Becerra-Fernandez, I., \& Leidner, D. E. (2008). Knowledge Management: An Evolutionary View. Armonk, NY: M. E. Sharpe.

Cook, C., Grammich, C., Lindenblatt, C., \& Moore, N.Y. (2004). Using A Spend Analysis to Help Identify Prospective Air Force Purchasing and Supply Management Initiatives. Santa Monica, CA: RAND.

Cox, A., Chicksand, D., \& Ireland, P. (2005). "Overcoming Demand Management Problems: The Scope for Improving Reactive and Proactive Supply Management in The UK Health Service." Journal of Public Procurement, 5(1): 1-22.

Defense Acquisition University (DAU). (n.d.). Services Acquisition Mall (SAM). [On-line]. Available at http://sam.dau.mil/Content.aspx? currentContentID=knowledge_based_services. [Retrieved August 1, 2013].

Defense Procurement and Acquisition Policy (DPAP). (2012). Defense pricing: Strategic sourcing. [On-line]. Available at www.acq.osd.mil/dpap/ss/. [Retrieved August 1, 2013].

Department of Defense (DoD). (2013). Better Buying Power. [On-line]. Available at www.acq.osd.mil/docs/USD(ATL)\%20Signed $\% 20$ Memo\%20to\%20Workforce\%20BBP\%202\%200\%20(13\%20Nov\% 2012)\%20with\%20attachments.pdf. [Retrieved August 1, 2013].

Dewhurst, M., Ellsworth, D., \& Hancock, B. (2013). "Redesigning Knowledge Work: How to Free Up High-End Experts to Do What They Do Best." Harvard Business Review, 91(1): 58-64. 
Ellram, L. M., Tate, W. L., \& Billington, C. (2007). "Services Supply Management: The Next Frontier for Improved Organizational Performance." California Management Review, 49(4): 44-66.

Fitzsimmons, J. A., \& Fitzsimmons, M. J. (2008). Service Management: Operations, Strategy, Information Technology (6th ed.). New York: McGraw-Hill \& Irwin.

Fontaine, M., \& Lesser, E. (2002, December). Challenges in Managing Organizational Knowledge. (Technical Report, 1-5.) Somers, NY: IBM Institute for Knowledge Based Organizations,

Freeman, E.R.. 1984. Strategic Management. Boston, MA: Pitman.

Government Accountability Office (GAO). (2004, September). Best Practices: Using Spend Analysis to Help Agencies Take a More Strategic Approach to Procurement (GAO-04-870). Washington, DC: Author.

Government Accountability Office (GAO). (2007, January). Defense Acquisitions: Dod Needs to Exert Management Oversight to Better Control Acquisition of Services (GAO-07-359T). Washington, DC: Author.

Government Accountability Office (GAO). (2009, April). Defense Acquisitions: Actions Needed to Ensure Value for Service Contracts (GAO-09-643T). Washington, DC: Author.

Government Accountability Office (GAO). (2013, April). Defense Contracting: Actions Needed to Increase Competition (GAO-13325). Washington, DC: Author.

Hansen, M., \& Nohria, N. (2004). "How to Build a Collaborative Advantage." MIT Sloan Management Review, 46(1): 22-30.

Hartley, J., Rashman, L., \& Withers, E. (2009). “Organizational Learning and Knowledge in Public Service Organizations: A Systematic Review of the Literature." International Journal of Management Reviews, 11(4): 463-494.

Hinson, C. \& McCue, C.P. (2004). Planning, Scheduling, and Requirements Analysis. Herndon, VA: National Institute of Governmental Purchasing. 
Holsapple, C., \& Wu, J. (2011). "An Elusive Antecedent of Superior Firm Performance: The Knowledge Management Factor." Decision Support Systems, 52(1): 271-283.

Husted, C. \& Reinecke, N., (2009). "Improving Public Sector Purchasing." McKinsey Quarterly, 4 (2): 18-25.

Kerlinger, F.N. \& Lee, H.B. (2000). Foundations of Behavioral Research (4th ed.). South Melbourne, Australia: Wadsworth Thomson Learning.

Kern, D., Moser, R., Sundaresan, N., \& Hartmann, E. (2011). "Purchasing Competence: A Stakeholder-Based Framework for Chief Purchasing Officers." Journal of Business Logistics, 32(2): 122-138.

Kraljic, P. (1983). "Purchasing Must Become Supply Management." Harvard Business Review, 61(5): 109-117.

Laplume, A.O. Sonpar, K. \& Litz, R.A. (2008). "Stakeholder Theory: Reviewing a Theory That Moves Us." Journal of Management, 34(6): 1152-1189.

Lovelock, C. H., \& Wirtz, J. (2007). Service Marketing: People, Technology, Strategy (6th ed.). Upper Saddle River, NJ: Pearson Prentice Hall.

McCue, Clifford P. and Johnson, Barbara R. (2010). Strategic Procurement Planning in the Public Sector. Herndon, VA: National Institute of Governmental Purchasing.

Monczka, R. M., \& Petersen, K. J. (2011). Supply Strategy Implementation: Current and Future Opportunities 2011. Tucson, AZ: CAPS Research, Institute of Supply Management.

Naval Sea Systems Command (2013). SeaPort-e. [On-line]. Available at www.seaport.navy.mil/default.aspx. [Retrieved July, 11, 2013].

Nelson, D., Moody, P.E., \& Stegner, J. (2001). The Purchasing Machine. New York: The Free Press.

Nissen, M. E. (2006). Harnessing Knowledge Dynamics: Principled Organizational Knowing \& Learning (pp. 1-278). Hershey, PA: IGI Global. 
Office of Management and Budget (OMB). (2005, May 20). "Implementing Strategic Sourcing" (Memorandum). Washington, DC: Author.

Office of the Under Secretary of Defense (OUSD). (2010, September). Better Buying Power: Guidance for Obtaining Greater Efficiency and Productivity In Defense Spending [Memorandum]. [On-line]. Available at www.acq.osd.mil/docs/USD_ATL_Guidance_Memo_ September_14_2010_FINAL.PDF. [Retrieved August 1, 2013].

Office of the Under Secretary of Defense (OUSD). (2010b, November). Taxonomy for the Acquisition of Services. [On-line]. Available at www.acq.osd.mil/dpap/dars/docs/USA006267-10-DPAP.pdf. [Retrieved August 1, 2013].

Pandit, K. \& Marmanis, H. (2008). Spend Analysis: The Window Into Strategic Sourcing. Fort Lauderdale, FL: J. Ross.

Pennington, R. (2011, April). “The Anatomy of Change: Georgia's State Procurement Transformation." Contract Management, (April): 20-29. [Online]. Available at www.ncmahq.org/files/ Articles/CM0411\%20-\%2020-29.pdf.

Project on Government Oversight (POGO). (2013, April 15). Public Comments on the Use of Cost Comparisons [Memorandum]. Washington, DC: Office of the Federal Procurement Policy and OMB.

Reese, D.L. \& PohIman D.W. (2005). "Centralized Purchasing Power: Why Air Force Leadership Should Care." Air Force Journal of Logistics, 29(1): 2-13.

Rendon, R.G., Apte, U. M., \& Apte, A. (2012). "Services Contracting in the DoD: A Comparison of Management Practices in the Army, Navy, and Air Force." Defense Acquisition Research Journal, 19(1): 3-32.

Sablan, M., (2011). "Assad Starts Department Wide Intelligent Business Discussion." Communicator, 11(2): 12-13.

Schiele, J. J. (2009). "Contributions of Public Purchasing Departments to Competitive Acquisition Processes for Consulting Services." Journal of Public Procurement, 9(2): 151-196. 
United States Court of Federal Claims (2010). Docket No. 09-602C, May 4, 2010. USfalcon, Inc. vs. United States. Washington, DC: Author.

Van der Valk, W., \& Rozemeijer, F. (2009). "Buying Business Services: Towards a Structured Service Purchasing Process." Journal of Services Marketing, 23(1): 3-10.

Van de Ven, A.H. (1989). "Nothing Is Quite so Practical as a Good Theory." Academy of Management Review, 14(4): 486-489.

Waterman, J., \& McCue, C. (2012). "Lean Thinking within Public Sector Purchasing Department: The Case of the U.K Public Service." Journal of Public Procurement, 12(4): 505-527.

Winter, S. G., \& Zollo, M. (2002). "Deliberate Learning and the Evolution Of Dynamic Capabilities." Organization Science, 13(3): 339-351.

Yin, R. K. (2009). Case Study Research: Design and Methods (4th ed.). Los Angeles: CA: Sage Publications. 